\title{
Vitamin D status and biomarkers of inflammation in runners
}

This article was published in the following Dove Press journal:

Open Access Journal of Sports Medicine

26 April 2012

Number of times this article has been viewed

\author{
Kentz S Willis' \\ Derek T Smith ${ }^{2}$ \\ Kenneth S Broughton ${ }^{3}$ \\ D Enette Larson-Meyer ${ }^{2,3}$ \\ 'Extension, ${ }^{2}$ Division of Kinesiology \\ and Health, ${ }^{3}$ Department of Family \\ and Consumer Sciences (Human \\ Nutrition), University of Wyoming, \\ Laramie, WY, USA
}

Background and purpose: The extra-skeletal functions of vitamin D - including its role in inflammatory modulation - are now well recognized but have not yet been investigated in an athletic population. Thus, the purpose of this study was to investigate the relationship between vitamin D status and pro- and anti-inflammatory cytokines (as markers of inflammation and immune system function) in endurance athletes.

Patients and methods: We analyzed fasting blood samples from 19 healthy, endurance-trained male and female runners (following a standardized diet and exercise regimen) for vitamin D status (serum 25-hydroxyvitamin D [25(OH)D)] and specific plasma cytokine concentrations (tumor necrosis factor alpha [TNF- $\alpha$ ], interferon-gamma [IFN- $\gamma]$, interleukin [IL]-4, and IL-10). Serum/plasma concentrations were log-transformed and simple regression analysis was used to determine significant associations between 25(OH)D and cytokine concentrations.

Results: Forty-two percent of participants had insufficient vitamin D status [25(OH)D $<32 \mathrm{ng} / \mathrm{mL}]$, whereas $11 \%$ were deficient $[25(\mathrm{OH}) \mathrm{D}<20 \mathrm{ng} / \mathrm{mL}]$. TNF- $\alpha$ and IL-4 were variable, ranging from 2.9 to $36.4 \mathrm{pg} / \mathrm{mL}$ and 0 to $252.1 \mathrm{pg} / \mathrm{mL}$, respectively. Concentrations of IFN- $\gamma$ and IL-10 were minimal, with means of $6.7 \pm 7.0 \mathrm{pg} / \mathrm{mL}$ and $4.8 \pm 5.1 \mathrm{pg} / \mathrm{mL}$, respectively. Regression analysis revealed a significant inverse association between $25(\mathrm{OH}) \mathrm{D}$ and TNF- $\alpha$ concentrations $\left(\mathrm{R}^{2}=56.5, P<0.001\right)$ but not between $25(\mathrm{OH}) \mathrm{D}$ and the remaining cytokines, IFN- $\gamma$, IL-4, and IL-10 ( $P=0.477,0.694$, and 0.673 , respectively).

Conclusion: These results call further attention to the epidemic of vitamin D insufficiency, even in outdoor athletes, and support a possible link between decreased vitamin D status and one particular marker of inflammation. Future investigations are necessary to determine whether increased inflammation in athletes with reduced vitamin D status could increase risk for inflammation-related injury.

Keywords: health, exercise training, tumor necrosis factor alpha, cytokines, injury risk

\section{Introduction}

It is now well recognized that vitamin D has many biological functions beyond its classical role in bone metabolism. ${ }^{1}$ As a steroid hormone, vitamin D functions, along with its nuclear vitamin D receptor, as a modulator of several hundred genes, many of which are involved in immune and inflammatory modulation. ${ }^{1,2}$ In fact, the vitamin $\mathrm{D}$ receptor has been identified in most immune system cells, including macrophages, neutrophils, dendritic cells, and T lymphocytes. ${ }^{3}$ Moreover, both 1-alpha hydroxylase, the enzyme responsible for converting 25-hydroxyvitamin D into hormonally active 1,25-dihydroxyvitamin $\mathrm{D}\left[1,25(\mathrm{OH})_{2} \mathrm{D}\right]$, and 24-hydroxylase, the major 1,25-dihydroxy vitamin D-degrading enzyme, are present in activated macrophages, suggesting that
Correspondence: D Enette Larson-Meye Department 3354, 1000 E University Avenue, University of Wyoming, Laramie, WY8207I, USA

Tel +l 3077664378

Fax +l 3077665686

Email enette@uwyo.edu
Open Access Journal of Sports Medicine 20 I 2:3 35-42

(c) 2012 Willis et al, publisher and licensee Dove Medical Press Ltd. This is an Open Access article

Dovepress

http://dx.doi.org// 0.21 47/OAJSM.S31022 
these phagocytic cells regulate the concentration of active vitamin D within the cell. ${ }^{1}$ Not surprisingly, vitamin D status is thought to have profound effects on many aspects of immune system function, ${ }^{3-5}$ including regulation of the cytokine environment. ${ }^{1}$

Over the past 10-15 years, much effort has been devoted to understanding the role of vitamin D in immune system modulation. ${ }^{4,6}$ In vitro studies have found defective macrophage function, including impaired chemotaxis, phagocytosis, and cytokine production, in vitamin D-deficient murine models. ${ }^{6}$ Animal studies, along with other in vitro work, have found that vitamin $\mathrm{D}$ enhances production of anti-inflammatory cytokines, including transforming growth factor beta-1 and interleukin (IL) $-4,{ }^{7}$ and reduces production of the proinflammatory cytokines IL-6, interferon- $\gamma($ IFN- $\gamma)$, IL-2, and tumor necrosis factor- $\alpha$ (TNF- $\alpha) .{ }^{8-13}$ In high concentrations, many pro-inflammatory cytokines, including TNF- $\alpha$, promote damage and/or impair recovery in cardiac, skeletal, and bone tissue. ${ }^{14-17}$ In vivo studies, however, have been less conclusive. Some studies demonstrate that vitamin D supplementation improves cytokine profiles in patients with chronic diseases, such as congestive heart failure and osteoporosis. ${ }^{18,19}$ Other studies in apparently healthy individuals have not clearly shown a link between vitamin D status and circulating cytokine concentrations. ${ }^{20-23}$

The relation between vitamin $\mathrm{D}$ status and cytokine profile in athletic populations is of considerable interest and has not, to our knowledge, been previously investigated. Athletes in intensive training often exhibit alterations in pro-inflammatory cytokine profiles, ${ }^{24}$ which have been hypothesized to influence risk for illness and overtraining syndrome. ${ }^{25,26}$ The purpose of this pilot study was to investigate the relation between vitamin D status and circulating cytokine concentrations (ie, as biomarkers of inflammation) in healthy, endurancetrained athletes. We chose to evaluate the inflammatory cytokines TNF- $\alpha$ and IFN- $\gamma$ as well as the anti-inflammatory cytokines IL-4 and IL-10. TNF- $\alpha$ was selected because of its inhibitory effect on muscle tissue repair following injury. ${ }^{16}$ The anti-inflammatory cytokine IL-10 was of interest because lower IL-10 concentrations have been identified in illness-prone runners. ${ }^{25}$ IFN- $\gamma$ and IL-4 were selected as key markers of the balance between T-helper $1\left(\mathrm{~T}_{\mathrm{H}} 1\right)$ and T-helper $2\left(\mathrm{~T}_{\mathrm{H}} 2\right)$ activity. ${ }^{1,4,26}$ We hypothesized that serum $25(\mathrm{OH}) \mathrm{D}$ concentrations, the most widely accepted marker of vitamin D status, would be inversely correlated with the pro-inflammatory cytokines TNF- $\alpha$ and IFN- $\gamma$ and directly correlated with the anti-inflammatory cytokines IL-4 and IL-10. Results will help guide future investigations into the possible contribution of vitamin D status toward inflammatory modulation and injury risk in athletes.

\section{Patients and methods}

Participants were healthy endurance-trained distance runners or triathletes $(n=19)$ between the ages of 19 and 45 years old who were recruited for a study assessing the effect of diet on intramyocellular lipid stores. ${ }^{27}$ To qualify, participants had to be running $\geq 30 \mathrm{~km} /$ week, have completed at least two training runs of greater than 2 hours within the past 3 months, and have a maximal oxygen uptake $\left(\mathrm{VO}_{2} \max \right) \geq 55 \mathrm{~mL} / \mathrm{kg} / \mathrm{min}$ for men and $\geq 50 \mathrm{~mL} / \mathrm{kg} / \mathrm{min}$ for women. The women had to have regularly occurring menstrual cycles. The original study was approved by the Institutional Review Board of the Pennington Biomedical Research Center. Further blood analysis was approved by the Institutional Review Board at the University of Wyoming. Before providing written informed consent, volunteers were fully informed about the possible risks of all procedures and that their blood samples would be archived for future analyses of nutrition-related parameters.

Prior to admission, volunteers were screened by a study physician and determined to be apparently healthy, free from acute injury and/or illness, and to have normal fasting insulin, glucose, and hemoglobin concentrations. Subjects were excluded if they smoked, demonstrated signs of a full or partial syndrome eating disorder, alcoholism, or other substance abuse problems, or were using prescription or over-the-counter medications or supplements (other than oral contraceptives) that could influence metabolism. To ensure qualification, $\mathrm{VO}_{2} \max$ was determined 2 to 3 weeks before initiation of the experimental protocol on a motordriven treadmill (MedTrack ST65, Quinton Industries, Inc, Bothell, WA), using a previously described protocol designed for endurance-trained runners. ${ }^{27,28}$ For descriptive purposes, body composition was also measured by dual-energy x-ray absorptiometry (DXA, Hologic QDR4500A, Hologic Inc, Bedford, MA).

Blood samples were collected in the morning, following an overnight fast (at least 12 hours after the participant's last meal) 3 days after following a controlled weight-maintenance diet (15\% protein, $25 \%$ fat, $60 \%$ carbohydrate) and exercise regimen. The details of the diets are described elsewhere. ${ }^{27}$ Briefly, well-balanced diets were designed by a Pennington Biomedical Research Center dietitian using commercially available foods and beverages and prepared by the center's metabolic kitchen staff. The subjects ate dinner at the center, and were given the following day's breakfast, lunch, and 
snacks to carry out. Subjects were asked to eat all food but to return anything not consumed to the research dietitian so it could be weighed and recorded. On days 1 and 2 of the controlled diet, the exercise regimen consisted of 45-minute training runs (on their own), which were to be completed at a target pace of $\sim 45 \mathrm{~s} /$ mile $(0.03 \mathrm{~s} /$ meter $)$ slower than their usual $10 \mathrm{~km}$ race pace. To ensure compliance, duration and timing of training runs were recorded in training logs and later reviewed by the researchers. No exercise was allowed on day 3 (the day before the blood draw). Female participants were studied in the follicular phase of their menstrual cycles (between days 1 and 10) or, if on birth control, while taking the placebo (no hormone) pills. Follicular status was verified by measurement of serum progesterone concentration (ie, progesterone concentration $<2.0 \mathrm{pg} / \mathrm{mL}$ ). Thus, blood samples were obtained at least 36 hours after the last bout of exercise and in the follicular phase of the menstrual cycle for female participants. This controlled diet, exercise, and timing regimen (for females) helped to ensure that inflammation and immune status were not inadvertently affected by recent nutrient intake and activities and were standardized within the sample.

Blood samples were collected following an overnight (12-hour) fast on the morning of day 4 (between 7 and 8 am), processed for serum and plasma extraction, and immediately frozen for storage at $-80^{\circ} \mathrm{F}$. Blood collected for serum analysis was allowed to clot for 30 minutes at room temperature before centrifugation at $3000 \mathrm{rpm}$ for 10 minutes. Serum $25(\mathrm{OH}) \mathrm{D}$ and parathyroid hormone $(\mathrm{PTH})$ concentrations were determined from archived (not previously thawed) serum samples via immunochemiluminometric assay by a commercial laboratory (IMCA, LabCorp, Burlington, NC). Plasma cytokine (TNF- $\alpha$, IFN- $\gamma$, IL-10, and IL-4) concentrations were assessed using commercially available enzyme immunometric assay kits (Assay Designs, Ann Arbor, MI). The intra-assay coefficient of variation for these procedures in our lab was $7.4 \%, 9.0 \%, 7.2 \%$, and $6.5 \%$ for IFN- $\gamma$, IL-4, IL-10, and TNF- $\alpha$, respectively. The intra-assay coefficients of variation listed by the manufacturer was $<10 \%$ for IFN- $\gamma$ and IL-4; 5.4\% for IL-10; and $4.7 \%$ for TNF- $\alpha$. In addition, assay sensitivities were $2-1000 \mathrm{pg} / \mathrm{mL}, 2-400 \mathrm{pg} / \mathrm{mL}$, $3.8-500 \mathrm{pg} / \mathrm{mL}$, and $8.4-1000 \mathrm{pg} / \mathrm{mL}$ for IFN- $\gamma$, IL-4, IL-10, and TNF- $\alpha$, respectively.

Statistical analyses were performed using Minitab ${ }^{\circledR}$ Statistical Software (v 15.1.0.0; State College, PA). Descriptive statistics were used to summarize the participants' physical characteristics, as well as circulating concentrations of 25(OH)D, PTH, and the plasma cytokines. Sex differences for physical characteristics and cytokine concentrations were assessed by two-sample $t$-test comparison or Mann-Whitney rank sum test when the assumption of normality was not met. All data are expressed as mean \pm standard deviation unless otherwise specified. Simple and multiple linear regression analysis was used to determine significant relations using vitamin D status as the independent variable (predictor) and the selected cytokine concentrations as the dependent variable (response variables) with and without inclusion of season/month as a covariate. Concentrations of interest were logarithmically transformed, when deemed appropriate (ie, when the sample was not normally distributed), to better describe the relative relationships involved. Alpha was set at 0.05 .

\section{Results}

The participants' descriptive characteristics are shown in Table 1. All were well-trained runners living in Baton Rouge, LA (latitude $=30^{\circ} 27^{\prime} \mathrm{N}$ ) who reported training between 30 and $85 \mathrm{~km} /$ week. All participants completed the dietary and controlled running regimen as assigned.

Results for vitamin D, PTH, and cytokine concentrations are reported in Table 2; these did not differ by sex. Eight (five male, three female) of the 19 participants (42\%) exhibited $25(\mathrm{OH}) \mathrm{D}$ concentrations below $32 \mathrm{ng} / \mathrm{mL}$, a commonly accepted threshold for insufficiency, ${ }^{29}$ and two participants (both male) had concentrations below $20 \mathrm{ng} / \mathrm{mL}$, the accepted threshold for deficiency. ${ }^{29,30}$ PTH concentrations ranged from 15-48 pg/mL and were within the normal range (12-65 pg/mL).

\section{Relation between vitamin D status, PTH concentration, and/or athlete characteristics}

Vitamin D status was not correlated with PTH concentration $\left(\mathrm{R}^{2}=0.0075, P=\mathrm{NS}\right)$ and was not associated with age,

Table I Physical characteristics of the 19 male and female endurance runners

\begin{tabular}{lcc}
\hline & Male $(\mathbf{n}=9)$ & Female $(\mathbf{n}=\mathbf{~ 1 0})$ \\
\hline Age $($ years $)$ & $27.4 \pm 9.4$ & $29.1 \pm 7.5$ \\
Height $(\mathrm{cm})$ & $177.3 \pm 7.4$ & $163.5 \pm 4.1^{*}$ \\
Weight $(\mathrm{kg})$ & $68.8 \pm 3.9$ & $56.2 \pm 4.9^{*}$ \\
Body fat $(\%)$ & $13.3 \pm 2.4$ & $20.6 \pm 2.3^{*}$ \\
$\mathrm{BMI}\left(\mathrm{kg} / \mathrm{m}^{2}\right)$ & $22.0 \pm 1.6$ & $21.0 \pm 1.1$ \\
$\mathrm{VO}_{2} \mathrm{max}$ & $62.4 \pm 4.9$ & $53.2 \pm 5.4^{*}$ \\
$(\mathrm{~mL} / \mathrm{kg} / \mathrm{min})$ & & \\
Training (miles/week) & $30.8 \pm 7.5$ & $34.7 \pm 12.2$ \\
\hline
\end{tabular}

Note: $* p<0.05$ compared with males.

Abbreviation: BMI, body mass index. 
Table 2 Vitamin D, parathyroid hormone (PTH), and cytokine concentrations in endurance-trained athletes

\begin{tabular}{lcc}
\hline & Male $(\mathbf{n}=\mathbf{9})$ & Female $(\mathbf{n}=1 \mathbf{0})$ \\
\hline $25(\mathrm{OH}) D(\mathrm{ng} / \mathrm{mL})$ & $33.8 \pm 14.0$ & $43.1 \pm 19.3$ \\
PTH $(\mathrm{pg} / \mathrm{mL})$ & $26.4 \pm 9.9$ & $28.8 \pm 6.9$ \\
TNF- $\alpha(\mathrm{pg} / \mathrm{mL})$ & $12.7 \pm 11.9$ & $8.9 \pm 6.9$ \\
$\mathrm{IFN}-\gamma(\mathrm{pg} / \mathrm{mL})$ & $5.0 \pm 3.3$ & $8.1 \pm 9.2$ \\
$\mathrm{IL}-4(\mathrm{pg} / \mathrm{mL})$ & $57.3 \pm 54.1$ & $75.0 \pm 80.5$ \\
$\mathrm{IL}-\mathrm{IO}(\mathrm{pg} / \mathrm{mL})$ & $3.8 \pm 4.2$ & $5.7 \pm 5.8$ \\
\hline
\end{tabular}

Note: No differences were found between male and female athletes. Abbreviations: 25(OH)D, 25-hydroxyvitamin D; PTH, parathyroid hormone; TNF- $\alpha$, tumor necrosis factor alpha; IFN- $\gamma$, interferon-gamma; IL, interleukin.

aerobic capacity, weekly training volume, weight, body fat percentage, self-reported vitamin supplementation, and season or month tested ( $P=\mathrm{NS}$; data not shown).

By simple correlation, 25(OH)D concentration was significantly inversely correlated with the circulating concentration of TNF- $\alpha\left(\mathrm{R}^{2}=0.41, P=0.004\right)$ (Figure 1A) but was not correlated with IFN- $\gamma$, IL-4, and IL-10 (data not shown, $P>0.05)$. The relation between 25(OH)D concentration and TNF- $\alpha$ remained after adjustment for both month and season tested $\left(\mathrm{R}^{2}=0.40\right.$ and 0.39 , respectively, $P<0.01)$. In a linear regression model, which included $25(\mathrm{OH}) \mathrm{D}$ concentration as the dependent variable and the cytokines as the independent variable (Model $\mathrm{R}^{2}=0.50$ ), TNF- $\alpha$ was the only significant variable $(P=0.015)$.

Additionally, due to the nature of the distribution of cytokine and 25(OH)D concentrations, data were log transformed. Following log-transformation, regression analysis for TNF- $\alpha$ and 25(OH)D concentrations (Figure 1B) revealed a better fit model $\left(\mathrm{R}^{2}=56.5, P<0.001\right)$ that resulted in a greatly improved residual distribution over the simple regression (Figure 1B) and better represented the relative nature of the relation. Further log-transformed regression analyses for the remaining cytokines were not significant, $\mathrm{R}^{2}=0.03,0.01$, and $0.01(P=\mathrm{NS})$ for IFN- $\gamma$, IL-4, and IL-10, respectively (not shown).

\section{Discussion}

The purpose of this pilot study was to investigate the regulation of specific pro- and anti-inflammatory cytokines as they relate to vitamin D status in well-trained endurance athletes. We hypothesized that serum 25(OH)D concentration would be inversely associated with the pro-inflammatory cytokines TNF- $\alpha$ and IFN- $\gamma$ and directly associated with the antiinflammatory cytokines IL-4 and IL-10. We discovered a surprisingly high prevalence of vitamin D insufficiency ( $42 \%)$ in this population of distance runners and a significant inverse association between 25(OH)D and TNF- $\alpha$ concentrations. Further, the regression curve representing this relation visibly steepened sharply as $25(\mathrm{OH}) \mathrm{D}$ concentrations began to drop below 30-32 ng/mL. Vitamin D status was not found to be associated with IFN- $\gamma$, IL-4, or IL-10, which could be reflective of a relatively low level of cytokine production in our healthy athletic population at rest.

The prevalence of vitamin D insufficiency and its potential health risks are well-characterized for the general population, ${ }^{31}$ but research on athletic populations is lacking. ${ }^{32} \mathrm{~A}$ study of French cyclists training 16 hours/week in Montpellier, France $\left(43.6^{\circ} \mathrm{N}\right)$, found that the group was, on average, only borderline sufficient $(25(\mathrm{OH}) \mathrm{D}=32.4 \pm 6.4 \mathrm{ng} / \mathrm{mL}$; mean \pm standard deviation) at the end of the competitive season. ${ }^{33}$ Another study of 93 middle eastern sportsmen, many of whom trained outdoors, found that $91 \%$ were vitamin $\mathrm{D}$ deficient $(25(\mathrm{OH}) \mathrm{D}<20 \mathrm{ng} / \mathrm{mL}) .{ }^{34}$ Several other studies $^{35-38}$ in mostly indoor athletes (gymnasts, dancers, basketball players) found that between $37 \%$ and $73 \%$ had low vitamin $\mathrm{D}$ status, although the thresholds for deficiency were remarkably low at $<15$ and $<10 \mathrm{ng} / \mathrm{mL}$ in two of these studies. ${ }^{35,39}$ As reported previously, ${ }^{32}$ our observed prevalence of insufficiency is in agreement with existing literature in the general population, ${ }^{40}$ but was nonetheless surprising considering the outdoor nature of endurance running and the southern location where our participants lived and trained (Baton Rouge, LA, latitude $=30^{\circ} 27^{\prime} \mathrm{N}$ ). Since the quantity of UV-B photons in midday sunlight is sufficient to stimulate endogenous vitamin D synthesis throughout the year in the southern part of the United States (latitudes $\left.<35^{\circ}\right),{ }^{41}$ insufficient status in our runners was most likely explained by training time in relation to peak sun exposure. ${ }^{31}$ Most likely our athletes - similar to the aforementioned middle eastern sportsmen ${ }^{34}$ - avoided training near solar noon and trained in the early morning or early evening when vitamin D is not likely to be synthesized even at latitudes close to the equator. ${ }^{31,42}$ It is also possible that our group of runners were habitual sunscreen users, which is known to inhibit endogenous vitamin D synthesis. ${ }^{43}$ In contrast to our findings, we also expected higher vitamin D status in endurance-trained athletes due to their higher energy needs, which we expected would increase intake of energy and macronutrients including vitamin D.

A second major finding of this study was the inverse association between 25(OH)D and TNF- $\alpha$ concentrations in healthy endurance-trained runners. We elected to investigate the relation between vitamin $\mathrm{D}$ status and selected cytokines because intense bouts of exercise are known to 
A

TNF- $\alpha=24.48-0.364725(\mathrm{OH}) \mathrm{D}$
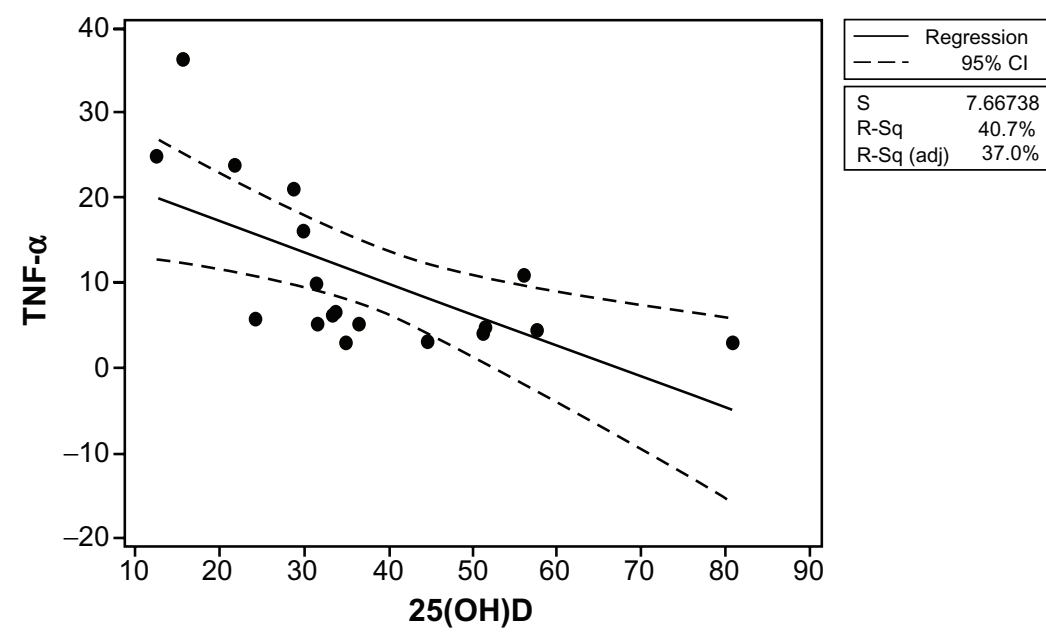

B

$\log 10(\mathrm{TNF}-\alpha)=2.860-1.283 \log 10(25(\mathrm{OH}) \mathrm{D})$

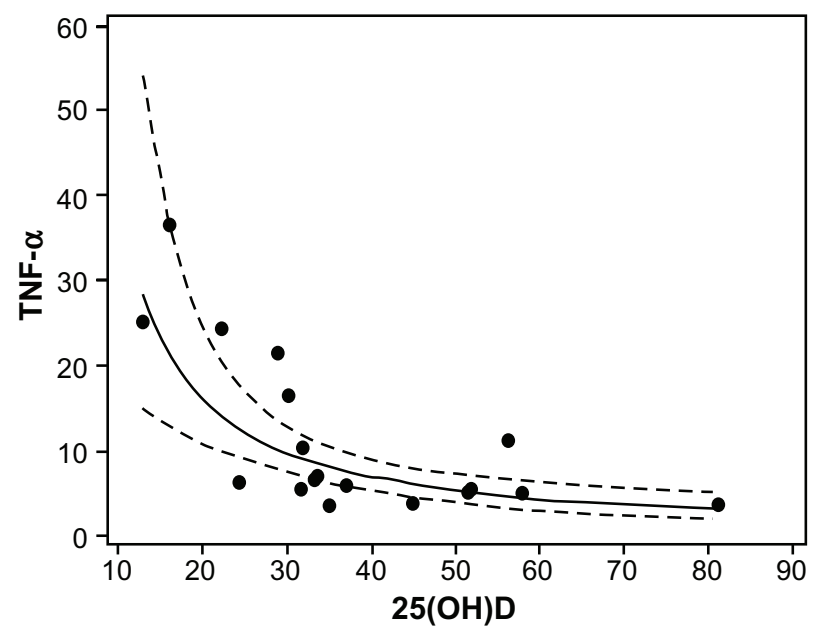

\begin{tabular}{|c|c|}
\hline$=\mathrm{Re}$ & $\begin{array}{l}\text { gression } \\
95 \% \mathrm{Cl}\end{array}$ \\
\hline $\mathrm{S}$ & 0.234441 \\
\hline R-Sq & $56.5 \%$ \\
\hline R-Sq (adj) & $53.8 \%$ \\
\hline
\end{tabular}

Figure I (A) Initial regression equation and 95\% confidence interval $(\mathrm{Cl})$ of relation between vitamin $\mathrm{D}$ status $[25(\mathrm{OH}) \mathrm{D}]$ and TNF- $\alpha$ concentrations. This was determined to be a poor model due to abnormal distribution of residuals. (B) Log-transformed regression equation and $95 \%$ confidence interval of relation between vitamin $\mathrm{D}$ status $[25(\mathrm{OH}) \mathrm{D}]$ and TNF- $\alpha$ concentrations.

Note: For every $72 \%$ increase in $25(\mathrm{OH}) \mathrm{D}$ concentrations, TNF- $\alpha$ concentrations were cut in half.

Abbreviations: $25(\mathrm{OH}) \mathrm{D}, 25$-hydroxyvitamin $\mathrm{D}$; TNF- $\alpha$, tumor necrosis factor alpha.

transiently alter circulating cytokines - to a degree similar to that induced by trauma or severe infection. ${ }^{24}$ Furthermore, alterations in the inflammatory cytokines occur to a variable degree in similarly trained individual athletes, and are hypothesized to play a role in immune suppression, injury risk, and overtraining syndrome. ${ }^{25,26,44}$ Because TNF- $\alpha$ is produced by a variety of cell types, including macrophages, monocytes, T-cells, smooth muscle cells, ${ }^{6,17}$ adipocytes, and fibroblasts, ${ }^{45}$ it is difficult to discern the tissue source or mechanism for the elevated circulating TNF- $\alpha$ concentration at rest. Interestingly, in the current study, circulating TNF- $\alpha$ concentration was not linearly elevated with decreasing $25(\mathrm{OH}) \mathrm{D}$ concentration but rather abruptly higher in those with insufficient vitamin D status (lower than 30-32 ng/mL). Our results are in agreement with in vitro and animal studies showing that vitamin $\mathrm{D}$ is capable of suppressing TNF- $\alpha$ synthesis, ${ }^{8,46-48}$ and in further support of previous crosssectional studies finding a negative association between vitamin D status and TNF- $\alpha$ in healthy young women, ${ }^{23}$ and in patients with congestive heart failure. ${ }^{49}$ In further support, several clinical trials in patients with chronic disease have found that vitamin D supplementation (which improves status) lowers TNF- $\alpha$ concentrations. ${ }^{18,19,50}$ The reason for the lack of an association with vitamin $\mathrm{D}$ and circulating concentrations of other cytokines in the current study is not known but is nevertheless in agreement with the aforementioned study by Peterson and Heffernan ${ }^{23}$ who also did not observe an association between vitamin $\mathrm{D}$ status and IL-10, despite the observed association with TNF- $\alpha$. In contrast, not all studies in healthy non-athletic populations 
have identified an association between low vitamin D status and elevated concentrations of TNF- $\alpha .^{20-22}$

The significance of the elevated resting TNF- $\alpha$ concentration in healthy athletes with insufficient vitamin $\mathrm{D}$ status is not known. Although TNF- $\alpha$ is thought to serve as a trigger for tissue repair and generation, ${ }^{51}$ it is also known to be a powerful muscle-wasting cytokine at chronically elevated concentrations. ${ }^{14}$ For example, TNF- $\alpha$ is shown to promote osteogenesis and migration of muscle-derived stromal cells and osteogenic differentiation at low concentrations, but this function is inhibited at high concentrations. ${ }^{15}$ Elevated TNF- $\alpha$ is also implicated in the delayed appearance of regenerating fibers in injured myocytes ${ }^{16,52}$ and in ischemia/reperfusion injury of cardiac muscle. ${ }^{17}$ Furthermore, in cardiac muscle, mice devoid of cardiac TNF- $\alpha$ (ie, TNF- $\alpha$ knockout mice) were found to be more resistant to ischemic/reperfusion injury than wild type mice, ${ }^{17}$ and treatment of rat heart with a TNF- $\alpha$ antibody before ischemic injury decreased the severity of injury and improved functional recovery. ${ }^{53}$

Currently, there is limited evidence directly linking compromised vitamin D status with increased risk or severity of sports-related inflammation or injury, or with overtraining syndrome. Quite curiously, the earliest recognition of such a link was alluded to in a German report in the 1950s that observed that athletes experienced a significant reduction in chronic pain due to sports injuries following an extensive six-week program of irradiation with a "central sun lamp" (on both sides of their bodies for up to 10 minutes, twice a week). ${ }^{54}$ Moreover, preliminary data from a study by Shindle and colleagues ${ }^{55}$ reported that professional football athletes who sustained a muscle injury had significantly lower vitamin D status than did teammates without muscle injury (19.9 vs $24.7 \mathrm{ng} / \mathrm{mL}$, respectively). In contrast, a recent study by Barker and colleagues ${ }^{22}$ did not find that elevated circulating concentrations of TNF- $\alpha$ or other inflammatory cytokines were associated with the delayed recovery of vitamin $\mathrm{D}$ insufficient $(25(\mathrm{OH}) \mathrm{D}<30 \mathrm{ng} / \mathrm{mL})$ patients following anterior cruciate ligament repair as compared to patients with sufficient status $(25(\mathrm{OH}) \mathrm{D}<30 \mathrm{ng} / \mathrm{mL})$. Thus, while it is certainly speculative that cytokine dysregulation due to insufficient vitamin D status has the potential to promote muscle damage and increase risk for injury in athletes, our data support the need for future studies to further evaluate the link between low vitamin D status and elevated TNF- $\alpha$ - as well as other cytokines - and to determine whether vitamin D supplementation, which improves status, modulates inflammation in athletes undergoing intense training.
Although this study presents compelling and novel findings on the relation between vitamin D status and inflammation in an athletic population, the retrospective nature limited some aspects of data collection. Specifically, vitamin D intake, sunscreen use, or time spent training during peak sunlight were not assessed, which would have provided insight into reasons for the observed high prevalence of vitamin D insufficiency. Furthermore, we were not able to collect longitudinal data on the incidence of training-associated injury. In addition, the 36-hour controlled rest period prior to blood draws may or may not be representative of the typical physiological state of an athlete in training. For example, while cytokines were measured a minimum of 36 hours following the last bout of exercise to avoid the potential for elevated cytokine profile due to recent intense exercise, it could be argued that such a state is not the typical physiological state for an athlete in training. Thus, the cytokine profiles under typical training conditions, which likely do not return to resting baseline between training sessions, should also be explored. Future investigations into the exercise-induced response of pro- and anti-inflammatory cytokines with respect to vitamin D status should provide further insight into the role of vitamin D in inflammatory modulation in athletes.

\section{Conclusion}

Our results call further attention to the epidemic of vitamin D insufficiency, and support a possible link between decreased vitamin D status and increased concentrations of the inflammatory cytokine TNF- $\alpha$. While the implications of this are not clear, future investigations should determine the possibility of vitamin D's influence on immune system function in athletes and active individuals.

\section{Acknowledgments}

This research was partially supported by NIH K01 DK062018.

\section{Disclosure}

The authors report no conflicts of interest in this work.

\section{References}

1. van Etten E, Mathieu C. Immunoregulation by 1,25-dihydroxyvitamin D3: basic concepts. J Steroid Biochem Mol Biol. 2005;97(1-2):93-101.

2. Cantorna MT, Mahon BD. D-hormone and the immune system. J Rheumatol Suppl. 2005;76:11-20.

3. White JH. Vitamin D signaling, infectious diseases, and regulation of innate immunity. Infect Immun. 2008;76(9):3837-3843.

4. Cantorna MT, Mahon BD. Mounting evidence for vitamin D as an environmental factor affecting autoimmune disease prevalence. Exp Biol Med (Maywood). 2004;229(11):1136-1142. 
5. Cannell JJ, Vieth R, Umhau JC, et al. Epidemic influenza and vitamin D. Epidemiol Infect. 2006;134(6):1129-1140.

6. Overbergh L, Decallonne B, Valckx D, et al. Identification and immune regulation of 25-hydroxyvitamin D-1-alpha-hydroxylase in murine macrophages. Clin Exp Immunol. 2000;120(1):139-146.

7. Cantorna MT, Woodward WD, Hayes CE, et al. 1,25-dihydroxyvitamin D3 is a positive regulator for the two anti-encephalitogenic cytokines TGF-beta 1 and IL-4. J Immunol. 1998;160(11):5314-5319.

8. Zhu Y, Mahon BD, Froicu M, et al. Calcium and 1 alpha,25dihydroxyvitamin D3 target the TNF-alpha pathway to suppress experimental inflammatory bowel disease. Eur J Immunol. 2005;35(1): 217-224.

9. Lemire JM. Immunomodulatory role of 1,25-dihydroxyvitamin D3. J Cell Biochem. 1992;49(1):26-31.

10. Rigby WF, Denome S, Fanger MW. Regulation of lymphokine production and human $\mathrm{T}$ lymphocyte activation by 1,25-dihydroxyvitamin D3. Specific inhibition at the level of messenger RNA. J Clin Invest. 1987; 79(6):1659-1664.

11. Rigby WF, Noelle RJ, Krause K, et al. The effects of 1,25-dihydroxy vitamin $\mathrm{D} 3$ on human $\mathrm{T}$ lymphocyte activation and proliferation: a cell cycle analysis. J Immunol. 1985;135(4):2279-2286.

12. Rigby WF, Stacy T, Fanger MW. Inhibition of T lymphocyte mitogenesis by 1,25-dihydroxyvitamin D3 (calcitriol). J Clin Invest. 1984;74(4): 1451-1455.

13. Muller K, Diamant M, Bendtzen K. Inhibition of production and function of interleukin- 6 by 1,25-dihydroxyvitamin D3. Immunol Lett. 1991;28(2):115-120.

14. Bhatnagar S, Panguluri SK, Gupta SK, et al. Tumor necrosis factor-alpha regulates distinct molecular pathways and gene networks in cultured skeletal muscle cells. PLoS One. 2010;5(10):e13262.

15. Glass GE, Chan JK, Freidin A, et al. TNF-alpha promotes fracture repair by augmenting the recruitment and differentiation of muscle-derived stromal cells. Proc Natl Acad Sci U S A. 2011;108(4):1585-1590.

16. Moresi V, Pristera A, Scicchitano BM, et al. Tumor necrosis factor-alpha inhibition of skeletal muscle regeneration is mediated by a caspasedependent stem cell response. Stem Cells. 2008;26(4):997-1008.

17. Maekawa N, Wada H, Kanda T, et al. Improved myocardial ischemia/ reperfusion injury in mice lacking tumor necrosis factor-alpha. $J \mathrm{Am}$ Coll Cardiol. 2002;39(7):1229-1235.

18. Inanir A, Ozoran K, Tutkak H, et al. The effects of calcitriol therapy on serum interleukin-1, interleukin-6 and tumour necrosis factor-alpha concentrations in post-menopausal patients with osteoporosis. J Int Med Res. 2004;32(6):570-582.

19. Schleithoff SS, Zittermann A, Tenderich G, et al. Vitamin D supplementation improves cytokine profiles in patients with congestive heart failure: a double-blind, randomized, placebo-controlled trial. Am J Clin Nutr. 2006;83(4):754-759.

20. Gannage-Yared MH, Azoury M, Mansour I, et al. Effects of a short-term calcium and vitamin D treatment on serum cytokines, bone markers, insulin and lipid concentrations in healthy post-menopausal women. $J$ Endocrinol Invest. 2003;26(8):748-753.

21. Shea MK, Booth SL, Massaro JM, et al. Vitamin K and vitamin D status: associations with inflammatory markers in the Framingham Offspring Study. Am J Epidemiol. 2008;167(3):313-320.

22. Barker T, Martins TB, Hill HR, et al. Low Vitamin D Impairs Strength Recovery After Anterior Cruciate Ligament Surgery. JEBCAM. 2011;16(3):201-209.

23. Peterson CA, Heffernan ME. Serum tumor necrosis factor-alpha concentrations are negatively correlated with serum $25(\mathrm{OH}) \mathrm{D}$ concentrations in healthy women. $J$ Inflamm (Lond). 2008;5:10.

24. Moldoveanu AI, Shephard RJ, Shek PN. The cytokine response to physical activity and training. Sports Med. 2001;31(2):115-144.

25. Cox AJ, Pyne DB, Saunders PU, et al. Cytokine responses to treadmill running in healthy and illness-prone athletes. Med Sci Sports Exerc. 2007;39(11):1918-1926.

26. Smith LL. Cytokine hypothesis of overtraining: a physiological adaptation to excessive stress? Med Sci Sports Exerc. 2000;32(2):317-331.
27. Larson-Meyer DE, Borkhsenious ON, Gullett JC, et al. Effect of Dietary Fat on Serum and Intramyocellular Lipids and Running Performance. Med Sci Sports Exerc. 2008;40(5):892-902.

28. Larson-Meyer DE, Hunter GR, Newcomer BR. Influence of endurance running and recovery diet on intramyocellular lipid content in women: A ${ }^{1}$ H-NMR study. Am J Physiol. 2002;282:E95-E106.

29. Hollis BW. Circulating 25-hydroxyvitamin D levels indicative of vitamin D sufficiency: implications for establishing a new effective dietary intake recommendation for vitamin D. J Nutr. 2005;135(2): 317-322.

30. Dawson-Hughes B, Heaney RP, Holick MF, et al. Estimates of optimal vitamin D status. Osteoporos Int. 2005;16(7):713-716.

31. Holick MF. Vitamin D deficiency. N Engl J Med. 2007;357(3): 266-281.

32. Larson-Meyer DE, Willis KS. Vitamin D and athletes. Curr Sports Med Rep. 2010;9(4):220-226.

33. Maimoun L, Manetta J, Couret I, et al. The intensity level of physical exercise and the bone metabolism response. Int J Sports Med. 2006; 27(2):105-111.

34. Hamilton B, Grantham J, Racinais S, et al. Vitamin D deficiency is endemic in Middle Eastern sportsmen. Public Health Nutr. 2010;13(10): $1528-1534$.

35. Bannert N, Starke I, Mohnike K, et al. Parameters of mineral metabolism in children and adolescents in athletic training. Kinderarztl Prax. 1991;59(5):153-156.

36. Bescos Garcia R, Rodriguez Guisado FA. Low levels of vitamin D in professional basketball players after wintertime: relationship with dietary intake of vitamin D and calcium. Nutr Hosp. 2011;26(5): 945-951.

37. Constantini NW, Arieli R, Chodick G, et al. High prevalence of vitamin D insufficiency in athletes and dancers. Clin J Sport Med. 2010;20(5): 368-371.

38. Lovell G. Vitamin D status of females in an elite gymnastics program. Clin J Sport Med. 2008;18(2):159-161.

39. Lehtonen-Veromaa M, Mottonen T, Irjala K, et al. Vitamin D intake is low and hypovitaminosis D common in healthy 9- to 15 -year-old Finnish girls. Eur J Clin Nutr. 1999;53(9):746-751.

40. Hanley DA, Davison KS. Vitamin D insufficiency in North America. J Nutr. 2005;135(2):332-337.

41. Webb AR, Kline L, Holick MF. Influence of season and latitude on the cutaneous synthesis of vitamin D3: exposure to winter sunlight in Boston and Edmonton will not promote vitamin D3 synthesis in human skin. J Clin Endocrinol Metab. 1988;67(2):373-378.

42. Webb AR. Who, what, where and when-influences on cutaneous vitamin $D$ synthesis. Prog Biophys Mol Biol. 2006;92(1):17-25.

43. Matsuoka LY, Ide L, Wortsman J, et al. Sunscreens suppress cutaneous vitamin D3 synthesis. J Clin Endocrinol Metab. 1987;64(6): $1165-1168$.

44. Willis KS, Peterson NJ, Larson-Meyer DE. Should we be concerned about the vitamin D status of athletes? Int J Sport Nutr Exerc Metab. 2008;18(2):204-224.

45. Popa C, Netea MG, van Riel PL, et al. The role of TNF-alpha in chronic inflammatory conditions, intermediary metabolism, and cardiovascular risk. J Lipid Res. 2007;48(4):751-762.

46. Giovannini L, Panichi V, Migliori M, et al. 1,25-dihydroxyvitamin D(3) dose-dependently inhibits LPS-induced cytokines production in PBMC modulating intracellular calcium. Transplant Proc. 2001; 33(3):2366-2368.

47. Cantorna MT, Hayes CE, DeLuca HF. 1,25-Dihydroxycholecalciferol inhibits the progression of arthritis in murine models of human arthritis. J Nutr. 1998;128(1):68-72.

48. Cohen ML, Douvdevani A, Chaimovitz C, et al. Regulation of TNFalpha by 1alpha,25-dihydroxyvitamin D3 in human macrophages from CAPD patients. Kidney Int. 2001;59(1):69-75.

49. Zittermann A, Schleithoff SS, Tenderich G, et al. Low vitamin D status: a contributing factor in the pathogenesis of congestive heart failure? J Am Coll Cardiol. 2003;41(1):105-112. 
50. Borazan A, Ustun H, Cefle A, et al. Comparative efficacy of oral and intravenous calcitriol treatment in haemodialysis patients: effects on serum biochemistry and cytokine levels. J Int Med Res. 2003;31(6): 489-496.

51. Chen SE, Gerken E, Zhang Y, et al. Role of TNF-\{alpha $\}$ signaling in regeneration of cardiotoxin-injured muscle. Am J Physiol Cell Physiol. 2005;289(5):C1179-C1187.

52. Coletti D, Moresi V, Adamo S, et al. Tumor necrosis factor-alpha gene transfer induces cachexia and inhibits muscle regeneration. Genesis. 2005;43(3):120-128.
53. Gurevitch J, Frolkis I, Yuhas Y, et al. Anti-tumor necrosis factor-alpha improves myocardial recovery after ischemia and reperfusion. $\mathrm{J} \mathrm{Am}$ Coll Cardiol. 1997;30(6):1554-1561.

54. Spellerberg AE. Increase of athletic effectiveness by systematic ultraviolet irradiation. Strahlentherapie. 1952;88(3-4):567-570.

55. Shindle M, Voos J, Gulotta L, et al. Vitamin D status in a professional American football team. Med Sci Sports Exerc. 2011;43(5): S340-S341.

\section{Publish your work in this journal}

Open Access Journal of Sports Medicine is an international, peer-reviewed, open access journal publishing original research, reports, reviews and commentaries on all areas of sports medicine. The manuscript management system is completely online and includes a very quick and fair peer-review system.
Visit http://www.dovepress.com/testimonials.php to read real quotes from published authors. 